\title{
Characteristics of illegal inland fishing according to the opinions of Polish fisheries guards
}

\author{
Maciej Mickiewicz, Arkadiusz Wołos, Marek Trella
}

Received - 27 January 2020/Accepted - 22 May 2020. Published online: 30 June 2020; Inland Fisheries Institute in Olsztyn, Poland Citation: Mickiewicz M., Wołos W., Trella M. 2020 - Characteristics of illegal inland fishing according to the opinions of Polish fisheries guards

- Fish. Aquat. Life 28: 125-132

\begin{abstract}
Poaching is still a great problem in Poland. Officers of the fisheries guard from three regions in northeast Poland rich in natural inland waters were surveyed. The most frequent type of poaching encountered by the officers was that practised by recreational fishers using rods (ranking of 4.4 points on a scale of $0-5$ ) followed by poaching stemming from poverty or unemployment (3.4 points), and poaching by professional fishermen was ranked the lowest (1.5 points). Organized poaching was identified as the most dangerous for ichthyofauna ( $42 \%$ of responses), followed by poaching by recreational fishers (28\%) and poaching stemming from poverty or unemployment (23\%). According to the officers surveyed, the species that were targeted by poachers most frequently were the predators: pike, Esox lucius (98\% of responses), European eel, Anguilla anguilla, pikeperch, Sander lucioperca and perch, Perca fluviatilis.
\end{abstract}

Keywords: illegal fishing, types of poaching, fishing gears, impact on fish stocks

\section{Introduction}

Fishing poaching dates back to the time of the first laws limiting fishing, which included catching fish

\footnotetext{
M.Mickiewicz, A.Wołos, M.Trella [ $\left.\Xi^{\circ}\right]$

Department of Fisheries Bioeconomics,

Stanisław Sakowicz Inland Fisheries Institute in Olsztyn, Poland

ul. Oczapowskiego 10, 10-719 Olsztyn, Poland

e-mail:m.trella@infish.com.pl
}

without permission or violating rules, and fishing in a manner or at a time that is not permitted. This definition implies that there were legal regulations in place or standards instituted by either people or organizations that limited making these kinds of catches. One of the oldest traditions associated with the obligatory limiting of fish catches comes from China. During the Qing dynasty, the authorities required that all fishers had the appropriate license to fish (Antony 2010). In Poland, poaching, which is understood as violating laws governing fishing, appeared simultaneously with Polish statehood during the early feudal period of the middle ages (Walachowicz 1963, Sługocki 1991) and almost certainly earlier, before written law was known, and common law and tradition guided ancestral and tribal communities.

Sir Izaak Walton, in his seminal work The Compleat Angler (Walton and Cotton 1985), first published in England in the mid-seventeenth century, mentions the threat of poaching to ichthyofauna; however, investigations of poaching as a phenomenon did not begin until much, much later. Poaching as a social and cultural phenomenon has been researched (Forsyth and Marckese 1993, von Essen et al. 2014), as have the reasons for violating the law and its consequences (von Essen et al. 2014). The impact of poaching on ichthyofauna (Kukuła

\footnotetext{
(c) Copyright by Stanisław Sakowicz Inland Fisheries Institute in Olsztyn.

C 2020 Author(s). This is an open access article licensed under the Creative Commons Attribution-NonCommercial-NoDerivs License (http://creativecommons.org/licenses/by-nc-nd/3.0/).
} 
2003, Hauge et al. 2009, von Essen et al. 2014) has been studied and, lastly, the phenomenon of poaching and its various aspects have been investigated in sociological research (Muth 1998, Forsyth and Marckese 1993, von Essen et al. 2014).

In the surveyed regions, fighting illegal fisheries is the responsibility of the State Fisheries Guard (SFG). The SFG is a specialist organizational unit that is immediately responsible to the voivodes. They function under the Regulation of April 18, 1985 on inland fisheries and all executive regulations issued based on it (Zębek and Napiórkowska-Krzebietke 2015). The officers are uniformed and armed, and they are licensed to use coercive measures and to impose fines as mandated by the criminal code. Thus, they have sufficient legal tools and technical measures to restrict poaching (Kucyk 2011); however, over the course of many years, increased tightening of the law in this area has been noted in Poland (Kosicki 2013).

This paper focuses on fisheries officers charged with combating poaching and their opinions on the threat poaching poses to the ichthyofauna in inland waters in Poland. The aim of the paper is to present how the effects of poaching are viewed by the enforcement service tasked with fighting this phenomenon.

\section{Materials and Methods}

The regions studied (Fig. 1) have many inland water basins, mainly lakes (including the largest in Poland - Śniardwy, Mamry, Łebsko, Jeziorak, Niegocin, Gardno, Wigry, Drużno, Nidzkie, Wdzydze, Charzykowskie, Bełdany, Ryńskie, Łańskie, Narie). The percentage of terrain covered by lakes in the
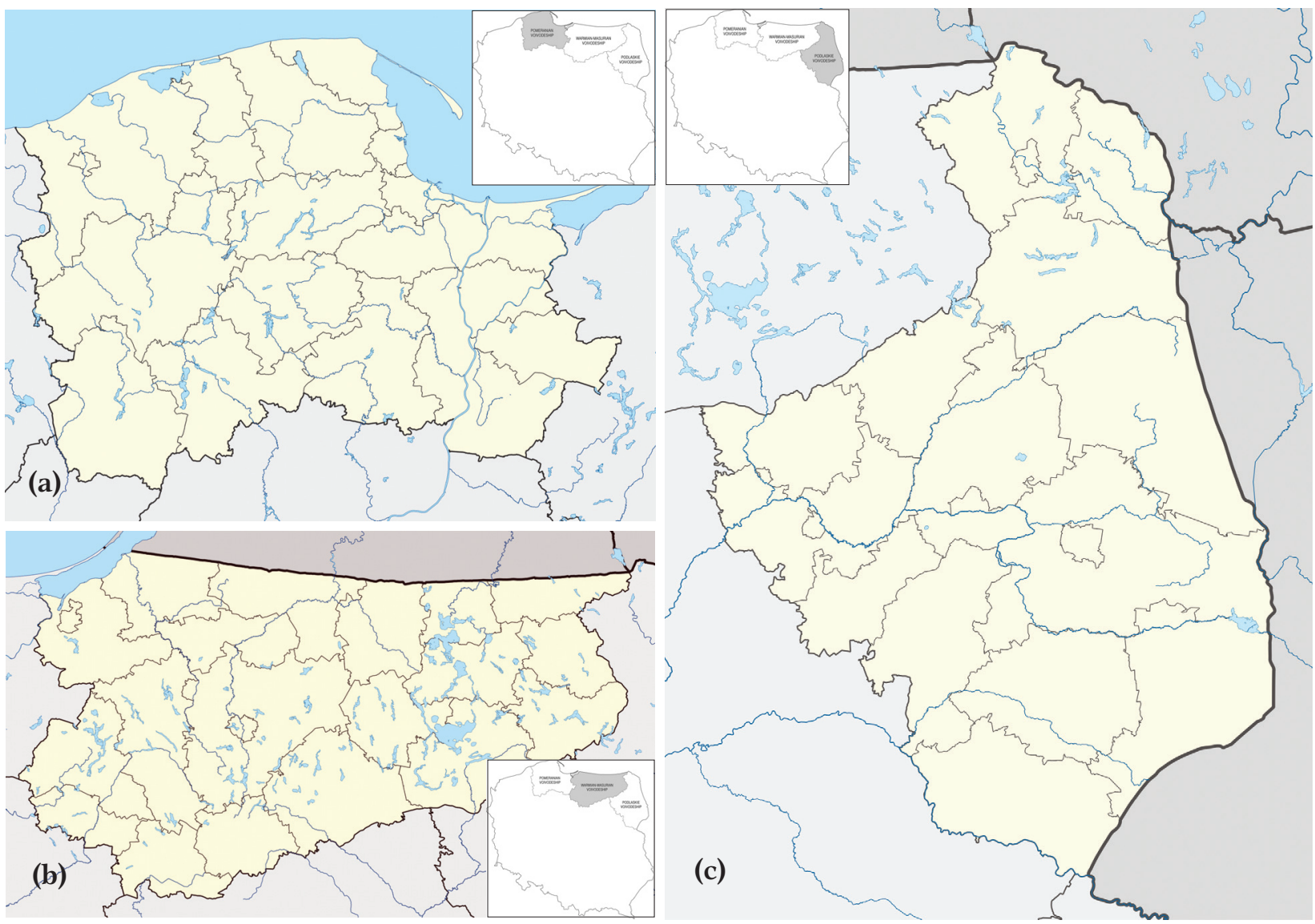

Figure 1. Map of Poland with the borders of the Pomeranian (a), Warmian-Masurian (b) and Podlaskie (c) voivodeships (https://pl.wikibooks.org/wiki/Wikibooks:Strona_g\%C5\%82\%C3\%B3wna). 
three voivodeships is $2.8 \%$ in the Pomorskie, $5.3 \%$ in the Warmińsko-Mazurskie and $0.7 \%$ in the Podlaskie voivodeships. For the sake of comparison, the percentage of Polish territory covered by lakes is 0.9\% (Kondracki 2002). Rivers (for example, the Vistula, Narew, Biebrza, Łyna, Pasłęka, Słupia, Łeba, Wierzyca, Wda, Drwęca, Czarna Hańcza) and canals (the Ostródzko-Elbląski, the Mazurski, the Augustowski - which is the oldest and longest in Poland) also occur in this region, as well as a large number of smaller streams that interconnect the lakes and rivers.

In this region of Poland aquatic tourism and recreation, including recreational fisheries, are especially well developed, and most of the nation's large lake fishery enterprises are in operation in this area. The large quantity of inland waters in the regions studied means that there might be noticeable poaching pressure, which is why this area was selected for study.

The research material comprised information obtained by analysing answers to questions given to fisheries guards in 2017-2018. The commandants of the voivodeship SFGs distributed questionnaires to SFG officers in the Pomorskie, Warmińsko-Mazurskie and Podlaskie voivodeships. Sixty-five surveys were sent, to all of the fishery guard officers employed at the SFG, and 60 were returned, which is a very satisfactory return rate of $92 \%$.

Table 1

Types of poaching most frequently encountered by the State Fisheries Guard

\begin{tabular}{|c|c|c|c|}
\hline Sequence & Type of poaching & $\begin{array}{l}\text { Mean rank } \\
\text { (on a scale of } 1-5 \text { points) }\end{array}$ & $\begin{array}{l}\text { Share }(\%) \text { of the maxi- } \\
\text { mum possible of total } \\
\text { rank } \\
(100 \%=300 \text { points })\end{array}$ \\
\hline 1 & Recreational poaching* & 4.4 & 88.7 \\
\hline 2 & Poaching stemming from poverty or unemployment** & 3.4 & 67.3 \\
\hline 3 & Poaching for personal use or an emotional thrill & 2.9 & 58.3 \\
\hline 4 & Organized poaching*** & 1.8 & 36.3 \\
\hline 5 & Violations by professional fishers $* * * *$ & 1.5 & 30.0 \\
\hline
\end{tabular}

*For example, recreational fishing without required permits, violating minimum fish sizes and closed fishing seasons, exceeding fishing limits, recreational fishing in restricted areas, using banned fishing methods, etc.;

**Usually done by individuals, possibly by two or three people, with the aim of selling the fish or for personal consumption;

*** So-called poaching gangs that supply, for example, hotels, bed and breakfast inns, camping grounds or vacation resorts;

****For example, fishing during closed periods without permission, using inappropriate meshes in nets, using without permission gears that span entire streams, fishing in banned areas, not adhering to protected fish sizes.
The surveys included questions regarding topics such as types of poaching and the threat they pose to fish, poaching methods and the threat they pose to ichthyofauna, the species targeted most often by poachers and the destruction and littering of lake shorelines and river banks by recreational fishers.

The survey was comprised of closed questions, i.e., the respondents were provided with options to choose from to answer questions and, for five questions, they were allowed to choose more than one answer, which is why the percentage share of responses does not always equal $100 \%$.

The information obtained from the SFG officers through the surveys was analysed using calculated percentages. Responses to questions about the types and methods of poaching were analysed using a ranking scale of 0 to 5 , on which 0 is a poaching type or method that was not noted, while 5 represents those encountered most often. The results are presented as percentages (\%) of the highest possible rank and as the mean rank. The highest possible rank of $100 \%$ was awarded when all respondents ranked a given factor 5 points. This means that over the entire analysed sample (60 individuals), 100\% corresponds to 300 points. The magnitude of the average rank is the arithmetic average of the sum of all ranks allocated to a factor. 


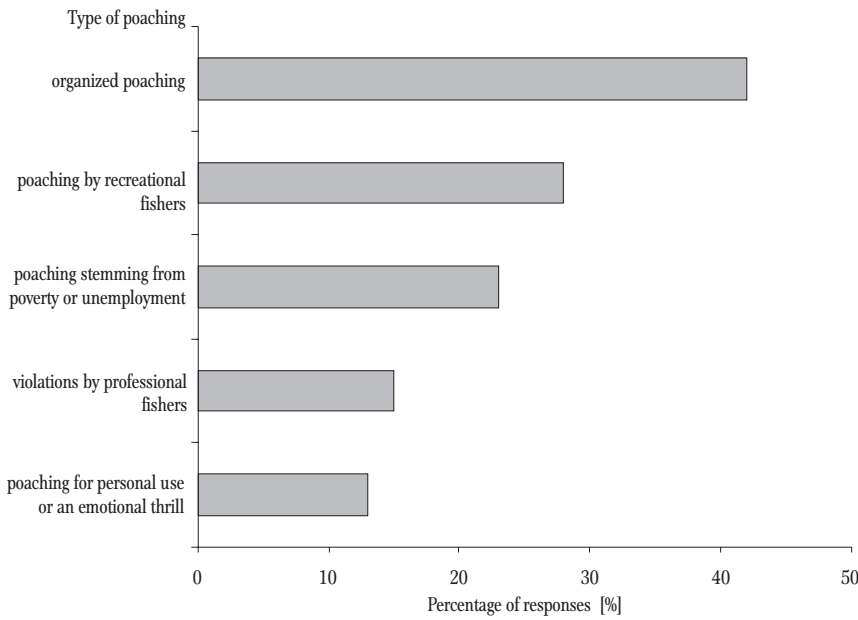

Figure 2. Percentages of responses (\%) to the following question: In your experience, which type of poaching method mentioned poses the greatest threat to fish?

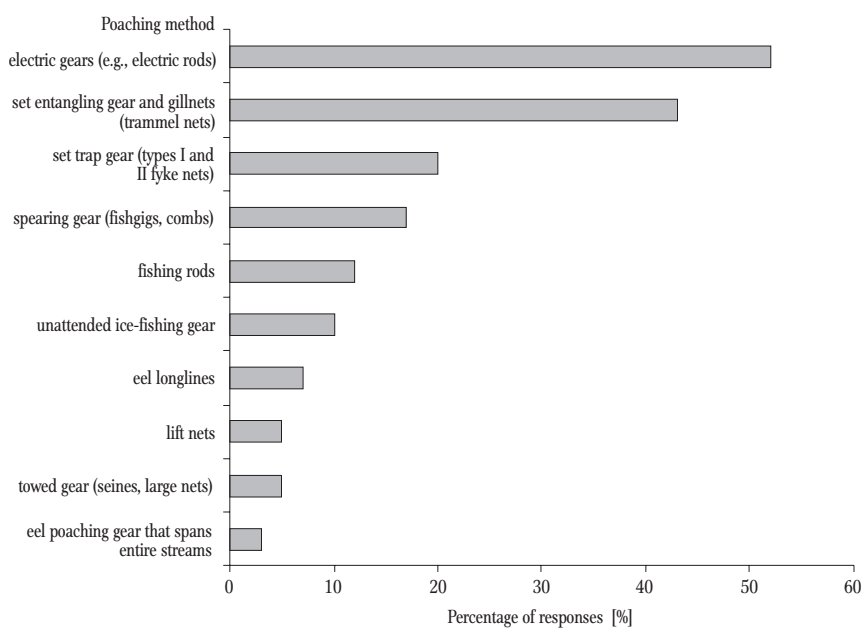

Figure 3. Distribution of responses (\%) to the following question: In your experience, which fishing gear used by poachers is the most threatening to fish?

\section{Results}

The surveyed SFG officers identified poaching committed by recreational fishers using fishing rods as the most common type of poaching with 4.4 points on the scale of 0 to 5 and $89 \%$ of the maximum ranking attainable (Table 1). The next type of poaching was that stemming from poverty or unemployment (3.4 points and slightly more than $67 \%$ ) and poaching for personal use or an emotional thrill (2.9 points and slightly more than 58\%). Organized poaching (1.8 points and about $36 \%)$ and violations committed by professional fishers (1.5 points and $30 \%)$ were at the bottom of the ranking.

The poaching type that the surveyed officers considered to pose the greatest threat to fish (Fig. 2) was organized poaching with $42 \%$ of the responses. Next, the respondents listed recreational poaching (28\%) and poaching stemming from poverty or unemployment (23\%). In the opinion of the respondents, the type of poaching that posed the least threat to fish was that committed by professional fishers (15\%) and poaching for personal use or an emotional thrill (13\%).

The SFG officers surveyed responded that the poaching methods they encountered most frequently were set entangling gear or gillnets (trammel nets) and rod fishing with 4.3 and 4.1 points on the scale of 0 to 5 points and approximately $85 \%$ and $81 \%$ of the maximum ranking (Table 2).

Table 2

Poaching methods encountered most frequently by officers of the State Fisheries Guard

\begin{tabular}{llll}
\hline \hline Sequence & Poaching methods & $\begin{array}{l}\text { Mean rank } \\
\text { (on a scale of 1-5 points) }\end{array}$ & $\begin{array}{l}\text { Share (\%) of the maximum } \\
\text { possible of total rank (100\% }= \\
300 \text { points) }\end{array}$ \\
\hline \hline 1 & Set entangling gear and gillnets & 4.3 & 85.3 \\
2 & Fishing rods & 4.1 & 81.0 \\
3 & Trap gear & 3.5 & 70.0 \\
4 & Unattended ice-fishing gear & 3.2 & 64.3 \\
5 & Spearing gear (fishgigs, combs) & 2.5 & 50.3 \\
6 & Eel longlines & 2.3 & 45.0 \\
7 & Eel poaching gear that spans entire streams & 2.2 & 44.0 \\
8 & Electric gear & 2.0 & 39.0 \\
9 & Lift nets & 1.3 & 26.7 \\
10 & Towed gear & 1.1 & 21.7 \\
\hline \hline
\end{tabular}


The next method was set trap gear (e.g. fyke nets) at 3.5 points and $70 \%$ and unattended ice-fishing gear at 3.2 points and slightly more than $64 \%$. The next methods encountered were fishgigs with 2.5 points and slightly more than $50 \%$, hook gear such as eel longlines at 2.3 points and $45 \%$, eel poaching gear that spans entire streams at 2.2 points and $44 \%$ and electric gear at 2.0 points and $39 \%$. The last position on the ranking was held by poaching with liftnets at

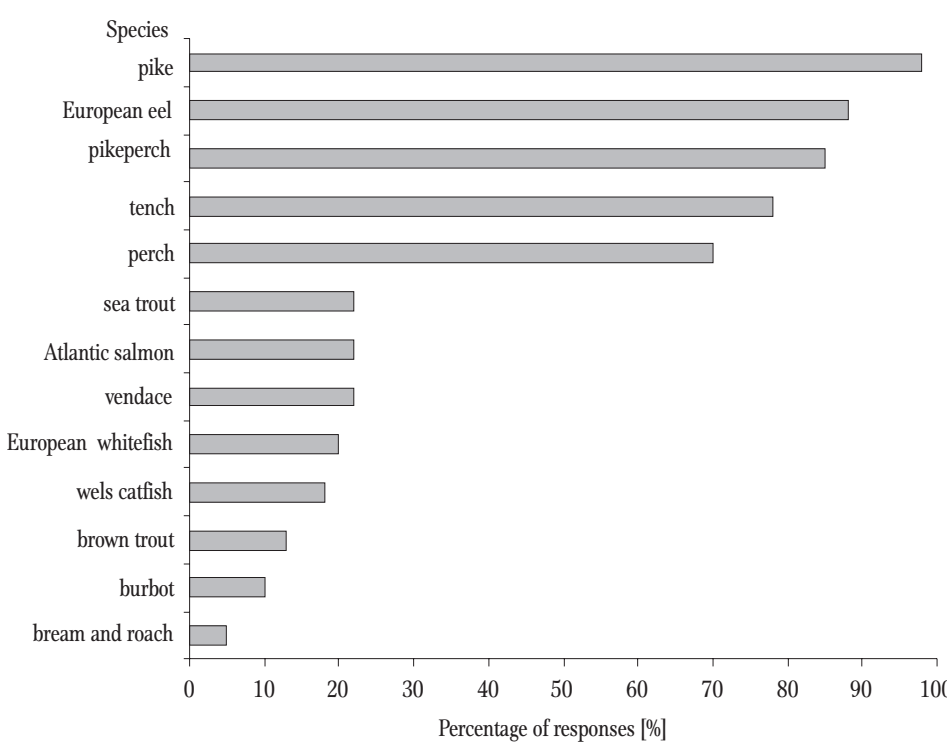

Figure 4. Distribution of responses (\%) to the following question: In your experience, which fish species do poachers target most frequently?

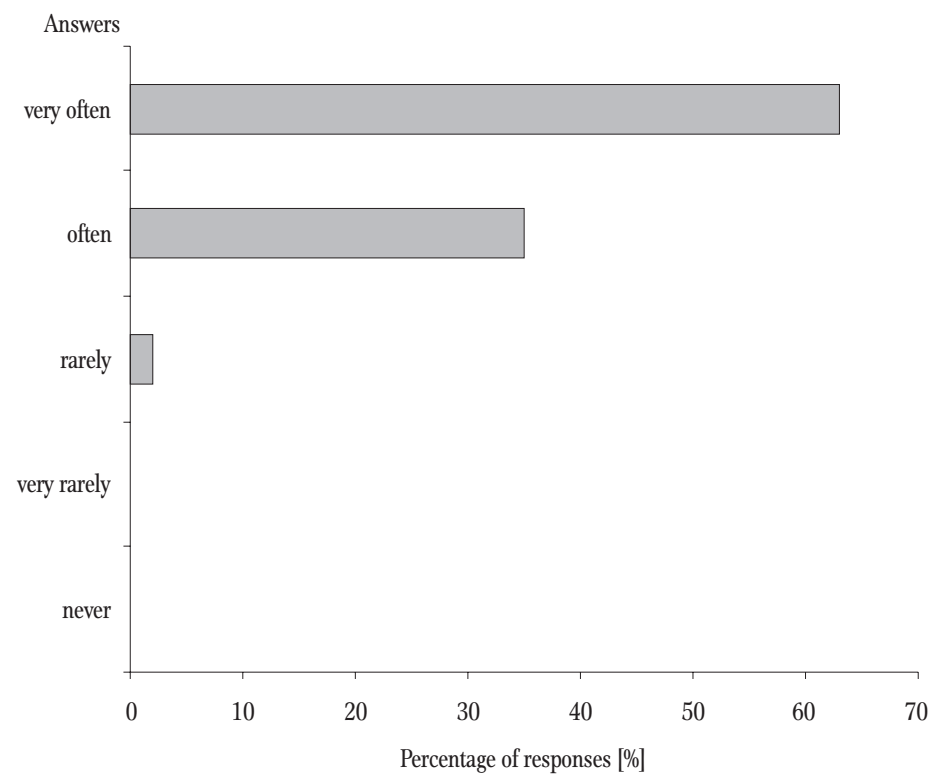

Figure 5. Percentages of responses (\%) to the following question: During the discharge of your duties, have you encountered evidence of the destruction or littering of lake shores or river banks by recreational fishers?
1.3 points and approximately $27 \%$ and towed gear (seines and large nets) at 1.1 points and approximately $22 \%$.

Among the poaching methods that the SFG officers considered to pose the greatest threat to the fish (Fig. 3) were electric gear (52\% of the responses) and set entangling or gillnet gear (43\%). Next, the respondents named poaching using trap gear (20\%), spearing gear $(17 \%)$, rods $(12 \%)$ and unattended ice-fishing gear (10\%). In the respondents' opinions, the poaching method that posed the least threat was that using hook gear (7\%), lift nets and towed gear (each at 5\%) and, lastly, poaching gear that spans entire streams (3\%).

According to the respondents, the fish that poachers targeted most frequently (Figure 4) were the predatory species: pike (98\% of responses), eel (88\%), pikeperch (85\%) and perch (70\%). Tench, Tinca tinca, was also ranked highly (78\%). Next came the valuable species of Atlantic salmon, Salmo salar, sea trout, Salmo trutta m. trutta (each at 22\%), vendace, Coregonus albula (22\%), European whitefish, Coregonus lavaretus (20\%) and brown trout, Salmo trutta m. fario (13\%). Wels catfish, Silurus glanis (18\%) and burbot, Lota lota $(10 \%)$, which are relatively rarely occurring predators, and bream, Abramis brama, and roach, Rutilus rutilus (each at $5 \%$ ), which are the two most common carp species in Polish waters, were at the end of the ranking. In the opinion of the respondents, no fish species threatened with extinction vimba bream, Vimba vimba, or Baltic sturgeon, Acipenser oxyrinchus, which are two anadromous migratory species that are currently being restored, were among those that are most frequently targeted by poachers.

Among the responses given to the question 'During the discharge of your duties, have you encountered evidence of the destruction or littering of lake shores or river banks by recreational fishers' answers 'often' and 'very often' dominated decidedly and their combined share was 98 (Fig. 5). 


\section{Discussion}

Illegal fishing as a method of securing food, because of low human population density, was conducted for many centuries on a relatively limited scale and, generally speaking, it did not disrupt the foundations of stocks of different fish species or the overall stability of ichthyofauna. As human populations grew, so did pressure on wild animals, and poaching began to have a measurable negative impact on both animals and the entire ecosystem. In the case of ichthyofauna, the most striking example of harmful poaching is the illegal catch of sturgeon, which is not only motivated by a desire for fish meat but more often for eggs (Ermolin and Svolkinas 2016, Masompour et al. 2018, van Uhm 2016a, 2016b, van Uhm and Siegel 2016). Consequently, many populations of sturgeon have been depleted, some species have been placed on endangered species lists (Cohen 1997), and in particular rivers large-scale conservation programmes have been implemented (Friedrich 2018).

Illegal and uncontrolled decreases in populations lead to impoverished genetic pools that result in the so-called bottleneck effect (Nei 2005). Poaching also has a negative impact on professional fisheries and on the results of recreational fishing (Gigliotti and Taylor 1990, Mayer et al. 2014, Mickiewicz and Wołos 2014). These real threats posed by poaching to both ecosystems and to those who exploit the gifts of nature have been a source of concern for many years (Muth 1998, Sethi and Hilborn 2008). Growing public disapproval coupled with the needs of nature conservation have caused government agencies (such as the SFG presented in this study) and increasing numbers of nature conservation groups to address the issue of limiting poaching (von Essen et al. 2014).

The results presented in this paper indicate that in fishery guards' opinions poaching is a serious problem in the north-eastern regions of Poland rich in inland waters. Among the types of poaching mentioned in the surveys, the type the officers mentioned most frequently was that committed by recreational fishers (at a mean of 4.4 points). This result corresponds with the other results presented. Firstly, the officers surveyed responded that the types of poaching that posed the greatest threat to the fish were organized poaching followed by recreational poaching (28\% of responses). Secondly, the respondents reported that the most common poaching gear was set entangling gear or gillnets followed by fishing rods used by recreational fishers (at an average of 4.1 points). Thirdly, in the opinions of the officers surveyed, among the poaching methods that posed the greatest threat to the fish, poaching with fishing rods was ranked number five out of the ten methods mentioned. Fourthly, the results of the study indicated that the officers surveyed often or very often encountered evidence of the destruction or littering of lake shores or river banks by recreational fishers (a total of $98 \%$ of the responses, including 'very often' at 63\%). Finally, although this is not such an obvious reference to recreational fishing, but rather an indirect one, among the fish that are targeted by poachers most frequently there were not only species of the greatest economic value (European eel, Atlantic salmon, migratory sea trout) but also species that fetch somewhat lower prices, such as vendace, European whitefish or tench (Mickiewicz 2014), while the predators - pike, pikeperch and perch - play a significant role in maintaining stability among the ichthyofauna and are the most desirable fish species among recreational fishers in Poland (Wołos 1991, Bnińska and Wołos 2001). The survey of illegal fishing in the Tisza River (Ukraine, another country of Central-Eastern Europe) revealed that in total 31 fish species were observed in poachers' catches, and electrofishing devices were the most effective illegal fishing gears as they caught the largest total number and weight of fish (Didenko et al. 2011).

Based upon the facts presented in this paper, one can conclude that recreational fishers in this part of Europe are not only a group of nature enthusiasts who spend time in the great outdoors while fishing recreationally in accordance with the ethics of and a dedication to the conservation of aquatic ecosystems, but they are also, at least in the opinions of the officers of the SFG, a group that poses a great 
poaching threat to ichthyofauna and aquatic ecosystems. If, in accordance with studies, in Poland roughly $10 \%$ of the estimated 700,000 recreational fishers and members of the Polish Angling Association (PAA) violate fishing regulations, then there are de facto approx. 70,000 poachers (Furdyna et al. 2011). If the number of recreational fishers who are not members of the PAA and those who poach using methods other than fishing rods are added to this figure, then the phenomenon of fisheries and recreational fisheries poaching in the whole country can be considered to be one that occurs on a massive scale. Already mentioned in the paper survey of illegal fishing in the Tisza River (Ukraine) stated that effects of poaching on local fish populations are currently probably lower than or comparable with that of recreational fishing (Didienko et al. 2011).

Thankfully, as one may surmise from the results presented, this is not organized poaching conducted with electric or towed gears, which are methods that are the most dangerous to fish. Usually, it is small-scale recreational poaching or that committed with set entangling gear or gill nets that is motivated by poverty or unemployment. The causes behind and the traditions of this type of poaching in Poland have been the focus of many studies and they have been investigated in detail by historians, sociologists, ethnographers and cultural anthropologists (Znamierowska-Prüfferowa 1988, Kłodnicki 1992, Olszewski 1993). One can only suppose that with the increasing wealth of society and decreasing unemployment that have followed on the heels of the political and economic transformations in Poland in the 1990s that poaching pressure on the ichthyofauna of Poland's inland waters will decrease. And this is what is indicated in this study - the 'centre of gravity' of poaching pressure has shifted from that committed with fisheries gear to that done with fishing rods. It would appear that a change in the mentality of recreational fishers is required to make a change in this state of affairs.

Author's contributions. M.M. wrote the paper; A.W. edited and corrected the paper; M.T. prepared figures and tables, followed up the process of the publication;
M.M. and A.W. suggested the topic, designed the study; M.M. and M.T. performed the statistical analysis, collected data, analyzed the data; M.M., A.W. and M.T. designed a survey and conducted the review of the literature.

ORCID ID

Marek Trella. (iD https://orcid.org/0000-0003-3700-1771

\section{References}

Antony R.J. 2010 - Elusive pirates, pervasive smugglers violence and clandestine trade in the Greater China Seas Hong Kong University Press, Hong Kong: 95-96.

Bnińska M., Wołos A. 2001. Management of selected Polish commercial and recreational lake fisheries activities Fish. Mgmt. Ecol. 8: 333-343.

Cohen A. 1997 - Sturgeon poaching and black market caviar: a case study - Environ. Biol. Fish. 48(1-4): 423-426.

Didenko A., Velykopolsky I., Buzevich I. 2011 - Illegal fishing in the Tisza River drainage within Ukraine: a threat for local fish stocks? - Arch. Pol. Fish. 19: 249-257.

Ermolin I., Svolkinas 2016 - Who owns sturgeon in the Caspian? New theoretical model of social responses towards state conservation policy - Biodivers Conserv. 25: 2929-2945.

Forsyth C.J., Marckese T. 1993 - Thrills and skills: a sociological analysis of poaching - Deviant Behaviour 14: 157-172.

Friedrich T. 2018 - Danube sturgeons: past and future - In: Riverine Ecosystem Management, Aquatic Ecology Series 8: 507-518.

Furdyna A., Koźmiński W., Leś E. 2011 - Monitoring the anti-poaching work of the State Fisheries Guard in the Western Pomeranian Voivodeship: Report for 2009-2011 - Towarzystwo Przyjaciół Rzek Iny i Gowienicy, Stepnica, 59 p. (in Polish).

Gigliotti L.M., Taylor W.W. 1990 - The effect of illegal harvest on recreational fisheries - North Amer. J. Fish. Management 10: 106-110.

Hauge K., Cleeland B., Wilson D. 2009 - Fisheries depletion and collapse - International Risk Governance Council, Geneva, 20 p.

Kłodnicki Z. 1992 - Traditional inland fisheries in Poland: a historical outline of methods, gears, and tools using retrogressive methods - Wydawnictwo Uniwersytetu Wrocławskiego, Wrocław, 405 p. (in Polish).

Kondracki J. 2002 - Regional geography of Poland Państwowe Wydawnictwo Naukowe, Warsaw, 440 p. (in Polish). 
Kosicki T. 2013 - Criminal liability for poaching according to the provisions of the Act - Hunting Law - Studia z Zakresu Nauk Prawnoustrojowych - Miscellanea 3: 155-166 (in Polish).

Kucyk R. 2011 - Evaluation of fisheries poaching threats in Polish inland waters - In: Fishers - condition of Polish inland fisheries (Ed.) M. Mizielin'ski, PZW, Warsaw: 37-44 (in Polish).

Kukuła K. 2003 - Structural changes in the ichthyofauna of the Carpathian tributaries of the River Vistula caused by anthropogenic factors - Supplementa ad Acta Hydrobiologica 4: 63 p.

Masompour Y., Gorgin S., Pighambari S.Y., Karimzadeh Gh., Babanejad M, Eighani M. 2018 - The impact of ghost fishing on catch rate and composition in the southern Caspian Sea - Marine Pollution Bulletin 135: 534-539.

Mayer J.E., King T.L., Birendra K.C., Will B., Peterson M.N. 2014 - Evaluating poaching deterrents in the Southeast Journal of the Southeastern Association of Fish and Wildlife Agencies 1: 146-149.

Mickiewicz M. 2014 - Comparison of mean prices of commercial fish and stocking material used by fisheries enterprises in fisheries zones in 2011 and 2013 - Komun. Ryb. 2: 1-5 (in Polish).

Mickiewicz M., Wołos A. 2014 - Administrative, legal, natural, and socioeconomic factors that impede the functioning and development of inland fisheries in Poland - Arch. Pol. Fish. 22: 281-288.

Muth R.M. 1998 - The persistence of poaching in advanced industrial society: meanings and motivations - an introductory comment - Soc. Nat. Res. 11: 5-7.

Nei M. 2005 - Bottlenecks, genetic polymorphism and speciation - Genetics 170(1): 1-4.

Olszewski W. 1993 - The history of Polish fishing from the end of the nineteenth century to the present. An ethnographic study - Wydawnictwo Uniwersytetu Mikołaja Kopernika, Toruń, 202 p.
Sethi S.R., Hilborn R. 2008 - Interactions between poaching and management policy. Affect marine reserves as conservation tools - Biol. Cons. 14: 506-516.

Sługocki J. 1991 - History of Polish law on fisheries - In: Studia nad rybołówstwem w Polsce (Ed.) T. Karwicka, Uniwersytet Mikołaja Kopernika, Toruń: 141-148 (in Polish).

van Uhm D. 2016a - The illegal wildlife trade. Inside the world of poachers, smugglers and traders - Studies of Organized Crime 15: 328 p.

van Uhm D. 2016b - "Black caviar" the illegal wildlife trade Part of the Studies of Organized Crime book series (SOOC) 15: 117-160.

van Uhm D., Siegel D. 2016 - The illegal trade in black caviar - Trends Organ. Crime 19: 67-87.

von Essen E., Hansen H.P., Nordström Källström H., Peterson M.N., Peterson T.R. 2014 - Deconstructing the poaching phenomenon - Brit. J. Crim. 54(4): 632-651.

Walachowicz J. 1963 - Princely monopolies within the treasury services of the early feudal ages in Western Pomerania - Poznańskie Towarzystwo Przyjaciół Nauk, Poznań, 61 p. (in Polish).

Walton I., Cotton C. 1985 - The Compleat Angler - London, Studio Editions, 427 p.

Wołos A. 1991 - Anglers' opinions as to the quality of the fishing and the fishery management in selected Polish waters - In: Catch effort sampling strategies. Their application in freshwater fisheries management (Ed.) I.G. Cowx, Fishing News Books: 134-142.

Zębek E., Napiórkowska-Krzebietke A. 2015 - Criminal and environmental aspects of illegal fishing - Studia Prawoustrojowe 29: 245-258 (in Polish).

Znamierowska-Prüfferowa M. 1988 - Traditional folk fisheries in Poland in the Collections and Studies of the Ethnographic Museum in Torun, Muzeum Etnograficzne w Toruniu, Toruń, 175 p. (in Polish). 